ARTICLE

\title{
Livestock enclosures in drylands of Sub-Saharan Africa are overlooked hotspots of $\mathrm{N}_{2} \mathrm{O}$ emissions
}

\author{
Klaus Butterbach-Bahl (10) ${ }^{1,2 \otimes}$, Gretchen Gettel (10 ${ }^{3}$, Ralf Kiese ${ }^{2}$, Kathrin Fuchs (1D) ${ }^{2}$, Christian Werner (1) ${ }^{2}$, \\ Jaber Rahimi ${ }^{2}$, Matti Barthel ${ }^{4} \&$ Lutz Merbold $^{1}$
}

Sub-Saharan Africa (SSA) is home to approximately $1 / 4$ of the global livestock population, which in the last 60 years has increased by factors of 2.5-4 times for cattle, goats and sheep. An important resource for pastoralists, most livestock live in semi-arid and arid environments, where they roam during the day and are kept in enclosures (or bomas) during the night. Manure, although rich in nitrogen, is rarely used, and therefore accumulates in bomas over time. Here we present in-situ measurements of $\mathrm{N}_{2} \mathrm{O}$ fluxes from 46 bomas in Kenya and show that even after 40 years following abandonment, fluxes are still one magnitude higher than those from adjacent savanna sites. Using maps of livestock distribution, we scaled our finding to SSA and found that abandoned bomas are significant hotspots for atmospheric $\mathrm{N}_{2} \mathrm{O}$ at the continental scale, contributing $\sim 5 \%$ of the current estimate of total anthropogenic $\mathrm{N}_{2} \mathrm{O}$ emissions for all of Africa.

\footnotetext{
${ }^{1}$ International Livestock Research Institute (ILRI), Mazingira Centre, PO Box 30709, Nairobi 00100, Kenya. ${ }^{2}$ Karlsruhe Institute of Technology, Institute of Meteorology \& Climate Research (IMK-IFU), Kreuzeckbahnstr. 19, 82467 Garmisch-Partenkirchen, Germany. ${ }^{3}$ IHE Delft Institute for Water Education, PO Box 3015, Westvest 7, 2611 AX Delft, The Netherlands. ${ }^{4}$ ETH Zurich, Sustainable Agroecosystems, Department of Environmental Systems Science, Universitätsstrasse 2, 8092 Zürich, Switzerland. ${ }^{{ }}$email: Klaus.Butterbach-Bahl@kit.edu
} 
A nthropogenic disturbance of the global nitrogen $(\mathrm{N})$ cycle has led to significant increases of atmospheric $\mathrm{N}_{2} \mathrm{O}$ concentrations from pre-industrial levels of $270 \mathrm{ppbv}$ to $331.1 \mathrm{ppbv}$ in $2018^{1}$. This has been mainly attributed to the increasing use of synthetic fertilizers since the 1950's to boost crop production ${ }^{2}$; however, $\mathrm{N}_{2} \mathrm{O}$ emissions associated with manure management is also one of the key drivers of atmospheric $\mathrm{N}_{2} \mathrm{O}$ increase since pre-industrial times ${ }^{3,4}$, with its current contribution estimated at $0.33 \mathrm{Tg} \mathrm{N}_{2} \mathrm{O} \mathrm{yr}^{-1}$ or $3 \%$ of all anthropogenic $\mathrm{N}_{2} \mathrm{O}$ sources ${ }^{5}$. Africa contains $20 \%, 27 \%$, and $32 \%$ of the global cattle, sheep, and goat populations ${ }^{6}$, with the majority of these populations roaming in semi-arid and arid environments $(63 \%, 82 \%$, and $70 \%$, respectively). Forming the economic backbone of pastoralist communities, livestock numbers have increased dramatically in the last 60 years, e.g., cattle increased from $\sim 120$ Mio head in 1960 to $>350$ Mio in $2018^{7}$ (Supplementary Fig. 1). These livestock are typically allowed to roam during the day for grazing and are held in temporary enclosures (in Swahili boma; in Afrikaans kraal) during the night, which can be used and subsequently abandoned any time from 1 month up to $\sim 10$ years. How the increase in livestock numbers, lack of manure spreading, and boma use and abandonment may have affected continental $\mathrm{N}_{2} \mathrm{O}$ emissions remains uncertain.

Grazing by livestock leads to a significant concentration of $\mathrm{N}$ in excreta, especially at low to medium feed quality, as only $7-33 \%$ of the ingested $\mathrm{N}$ is metabolized and the remaining $\mathrm{N}$ is excreted as dung or urine ${ }^{8,9}$. This change in $\mathrm{N}$ cycling may be particularly important in the semi-arid and arid regions of SSA (as well as other parts of the world), where pastoralist communities practice livestock production in traditional ways (Supplementary Fig. 2). Pastoralist communities do not typically use manure for fertilizer, as they do not produce crops in large amounts, if at all. As a result, manure accumulates in bomas, which after years can be up to several meters in height. Bomas are periodically abandoned when communities decide to move owing to, e.g., changes in resource availability. Manure remains in place, forming islands of soil fertility high in $\mathrm{C}, \mathrm{N}$, and $\mathrm{P}$, which ultimately increases spatial heterogeneity in savanna landscapes and supports increased plant biomass and forage quality for many decades ${ }^{10,11}$. Bomas remain visible in the landscape even after years of abandonment as grassy glades, which attract wildlife, particularly large herbivores, who in turn deposit dung and maintain bomas as nutrient hotspots for decades up to thousands of years ${ }^{12,13}$.

Although a number of studies have focused on the importance of abandoned bomas as soil fertility hotspots and their role in landscape and ecosystem diversity ${ }^{10-13}$, the importance of bomas as possible landscape hotspots of soil $\mathrm{N}_{2} \mathrm{O}$ emissions remains unexplored. Other studies across various systems and climates have shown that $\mathrm{N}_{2} \mathrm{O}$ emissions are positively related to soil $\mathrm{N}$ availability ${ }^{14}$. To test the hypothesis that bomas are spatial hotspots of $\mathrm{N}_{2} \mathrm{O}$ emissions in semi-arid and arid regions of SSA at decadal time scales, we measured fluxes at abandoned bomas across an age gradient as well as in adjacent savanna sites in Kenya, East Africa (Fig. 1).

$\mathrm{N}_{2} \mathrm{O}$ fluxes were measured using the fast-box chamber method $^{15}$ at seven different locations across Kenya at a total of forty-six boma sites, differing in age after abandonment (0.1-40 years) and at 22 adjacent savanna sites. In total, 257 flux measurements were conducted during the wet and dry seasons in 2018-2019 and were complemented by measurements of soil temperature and gravimetric water content. At all sites, we quantified the concentrations of soil $\mathrm{C}$ and $\mathrm{N}$ content at $0-10 \mathrm{~cm}$ depth, and at $0-1 \mathrm{~m}$ depth at a subset of sites (Kapiti Research Station, Mpala Research Centre, and Ol Kirimatien Group Ranch). Bomas that were abandoned from 0 to 15 years generally had no or little vegetation cover, likely a result of high nutrient concentrations. We therefore recorded vegetation presence and absence at each measuring site. We also observed an organic layer thickness of $>0.3 \mathrm{~m}$, indicating that the boma was used for consecutive years. In order to estimate measurement biases associated with day-time sampling, we investigated diurnal patterns of $\mathrm{N}_{2} \mathrm{O}$ emissions at a boma site at Kapiti Research Station. Furthermore, we explored short-term effects of rainfall on $\mathrm{N}_{2} \mathrm{O}$ fluxes by simulating a rain event by artificially adding water to a number of different bomas and adjacent savanna sites at the Mpala Research Centre.

Our results show that abandoned bomas remain active hotspots for $\mathrm{N}_{2} \mathrm{O}$ emissions for at least four decades, remaining about one order of magnitude higher than the savanna. Scaling this finding to SSA reveals that bomas are a neglected source for atmospheric $\mathrm{N}_{2} \mathrm{O}$ at the continental scale, with emissions more than doubling due to the increase in livestock in semi-arid and arid environments in the last 60 years. Based on our calculations, we estimate that bomas currently contribute about $5 \%$ of the current total anthropogenic $\mathrm{N}_{2} \mathrm{O}$ emissions for the continent of Africa.

\section{Results and discussion}

Comparing $\mathrm{N}_{2} \mathrm{O}$ fluxes from savanna and abandoned boma sites. In agreement with earlier studies ${ }^{11,12}$, we found higher $\mathrm{C}$ and $\mathrm{N}$ concentrations and stocks in the top $0-20 \mathrm{~cm}$ (in our study up to a magnitude higher) than in adjacent savanna soils, especially in bomas that were used for more than one year (Supplementary Table 1 and Supplementary Fig. 3). $\mathrm{N}_{2} \mathrm{O}$ fluxes at boma sites $(n=$ 46) varied over five orders of magnitudes from $9.3-10,266 \mu \mathrm{g} \mathrm{N}_{2} \mathrm{O}$ $\mathrm{N} \mathrm{m}^{-2} \mathrm{~h}^{-1}$ (mean: $643 \pm 255 \mu \mathrm{g} \mathrm{N} \mathrm{N}_{2} \mathrm{O}-\mathrm{N} \mathrm{m}^{-2} \mathrm{~h}^{-1}, \quad n=187$ flux measurements in total), whereas fluxes at savanna sites $(n=22)$ had lower variation and were on average two orders of magnitudes lower (mean: $5.5 \pm 1.0 \mu \mathrm{g} \mathrm{N}_{2} \mathrm{O}-\mathrm{N} \mathrm{m}^{-2} \mathrm{~h}^{-1}$, range: -0.7 to $15.9 \mu \mathrm{g} \mathrm{N} \mathrm{N}_{2} \mathrm{O}-\mathrm{N}$ $\mathrm{m}^{-2} \mathrm{~h}^{-1}, n=70$ flux measurements). Boma sites without vegetation $(n=18)$ emitted significantly more $\mathrm{N}_{2} \mathrm{O}\left(981 \pm 408 \mu \mathrm{g} \mathrm{N} \mathrm{N}_{2} \mathrm{O}-\mathrm{N} \mathrm{m}^{-2}\right.$ $\left.\mathrm{h}^{-1}, n=107\right)$ than older boma sites $(n=28)$, which had plant cover $\left(119 \pm 48 \mu \mathrm{g} \mathrm{N}_{2} \mathrm{O}-\mathrm{N} \mathrm{m}^{-2} \mathrm{~h}^{-1}, n=80\right)$. Bomas with an organic layer thickness $>0.3 \mathrm{~m}(n=24)$ showed significantly higher $\mathrm{N}_{2} \mathrm{O}$ emissions $\left(1125 \pm 471 \mu \mathrm{g} \mathrm{N} \mathrm{N}_{2} \mathrm{O}-\mathrm{N} \mathrm{m}^{-2} \mathrm{~h}^{-1}\right)$ than bomas with a shallow organic layer $(n=22)\left(119 \pm 40 \mu \mathrm{g} \mathrm{N}_{2} \mathrm{O}-\mathrm{N} \mathrm{m}^{-2} \mathrm{~h}^{-1}\right)^{16}$.

$\mathrm{N}_{2} \mathrm{O}$ fluxes declined exponentially with time since boma abandonment (Fig. 2), this also corresponded to a negative correlation of soil $\mathrm{N}$ content (\%) with boma age (Supplementary Fig. 4), which was consistent with our hypothesis and previous studies $^{14}$.

There was no relationship between $\mathrm{N}_{2} \mathrm{O}$ fluxes and soil moisture across the 46 boma sites in our data set. However, the simulated rainfall event enhanced average $\mathrm{N}_{2} \mathrm{O}$ fluxes by a factor of 3 for $~ 60$ hours (from $20.0 \pm 4.2 \mu \mathrm{g} \mathrm{N}_{2} \mathrm{O}-\mathrm{N} \mathrm{m}^{-2} \mathrm{~h}^{-1}$ to $56.1 \pm$ $12.6 \mu \mathrm{g} \mathrm{N} \mathrm{N}_{2} \mathrm{O}-\mathrm{N} \mathrm{m}^{-2} \mathrm{~h}^{-1}$ ) (Supplementary Fig. 5). This contrasted with results observed for the neighboring savanna sites, which showed no enhancement of $\mathrm{N}_{2} \mathrm{O}$ fluxes with rainfall (before: 0.6 $\pm 0.5 \mu \mathrm{g} \mathrm{N} \mathrm{N}_{2} \mathrm{O}-\mathrm{N} \mathrm{m}^{-2} \mathrm{~h}^{-1}$, after simulated rainfall: $0.9 \pm 0.5 \mu \mathrm{g}$ $\mathrm{N}_{2} \mathrm{O}-\mathrm{N} \mathrm{m}^{-2} \mathrm{~h}^{-1}$ ). With respect to diurnal variation, measurements revealed that soil $\mathrm{N}_{2} \mathrm{O}$ fluxes were approximately two times higher in the afternoon than in the morning hours (Supplementary Fig. 6). We performed the measurements in this study in the morning hours and on days without rainfall, so we consider these measurements to be biased towards the low-end of potential $\mathrm{N}_{2} \mathrm{O}$ emission estimates.

Bomas as sources of $\mathrm{N}_{2} \mathrm{O}$ at the continental scale. To assess whether our findings of elevated $\mathrm{N}_{2} \mathrm{O}$ fluxes from bomas are relevant at the scale of Africa and at decadal time-periods, we first calculated cumulative $\mathrm{N}_{2} \mathrm{O}$ emissions for a 40 -year period 

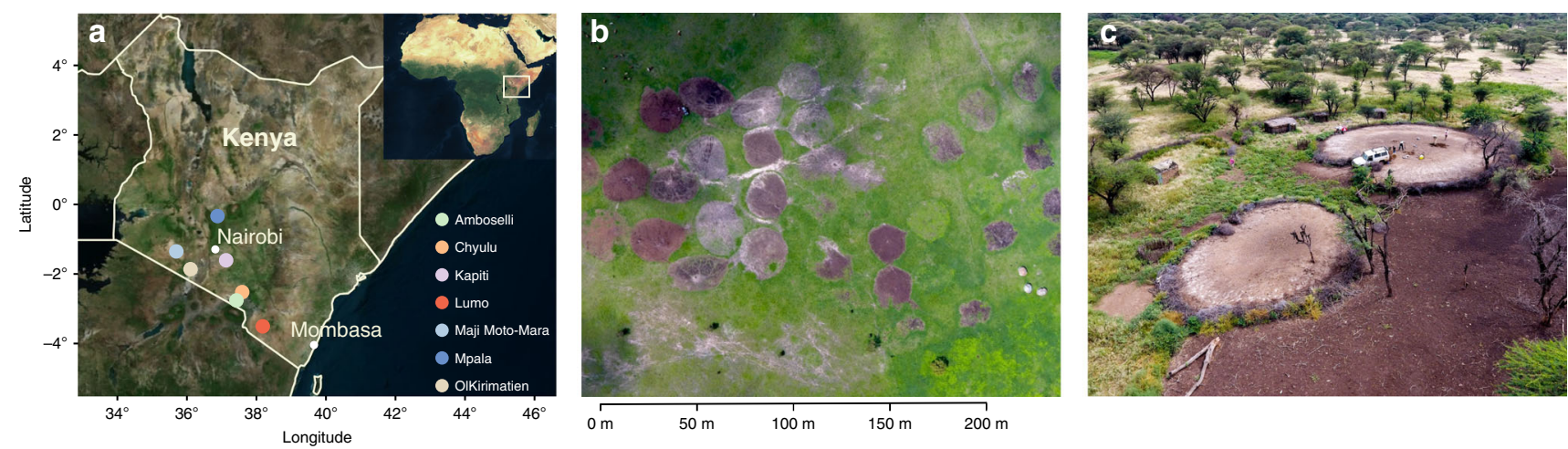

Fig. 1 Location of study sites and aerial photos of bomas. a Position of measuring locations across Kenya; $\mathbf{b}$ aerial picture of bomas at Kapiti Research Station; and c measurement of $\mathrm{N}_{2} \mathrm{O}$ fluxes at boma sites at Ol Kirimatien Group Ranch in South-west Kenya.

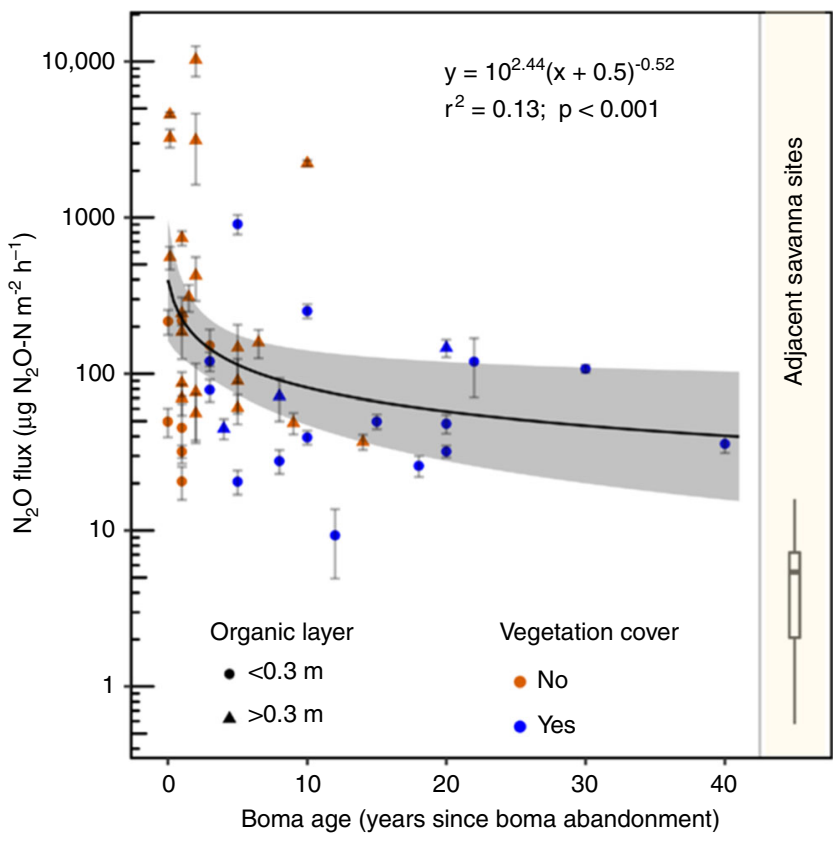

Fig. $2 \mathrm{~N}_{\mathbf{2}} \mathrm{O}$ fluxes from bomas (0.1-40 years old) and savanna sites. This figure shows data for bomas sampled in Kenya from 0.1 to 40 years in comparison with fluxes at adjacent savanna sites. Round symbols refer to boma sites with organic layer thickness of $<0.3 \mathrm{~m}$, whereas triangles indicate that the organic layer thickness is $>0.3 \mathrm{~m}$. Bomas without vegetation cover are marked by orange symbols, whereas blue symbols show bomas with vegetation cover. Details on the regression are given in Supplementary Table 2. The 95\% confidence interval for the regression is highlighted in gray. Error bars indicate the standard error of the mean for each boma. Distribution of fluxes for adjacent savanna sites are

summarized in a box plot (dark line depicts the median; box shows $25-75 \%$ percentiles, and whiskers depict range of measurements). Given their small magnitude, savanna sites were not considered as background in the boma flux calculations.

following abandonment using the exponential regression curve of Fig. 2. We consider this to be a conservative estimate because we did not include the range of variation from diurnal measurements or pulse emissions of $\mathrm{N}_{2} \mathrm{O}$ following rainfall events. This calculation resulted in a cumulative mean emission rate of $25 \mathrm{~g} \mathrm{~N}_{2} \mathrm{O}-\mathrm{N}$ per $\mathrm{m}^{-2}$ boma area over 40 years (95\% confidence interval, CI: 13.3-48.1 $\mathrm{g} \mathrm{N}_{2} \mathrm{O}-\mathrm{N} \mathrm{m}^{-2}$ ) and a mean annual rate of $0.62 \mathrm{~g} \mathrm{~N}_{2} \mathrm{O}$ $\mathrm{N} \mathrm{m}^{-2}$ (CI: $0.33-1.20 \mathrm{~g} \mathrm{~N}_{2} \mathrm{O}-\mathrm{N} \mathrm{m}^{-2} \mathrm{yr}^{-1}$ ). In order to scale up these estimates to the continent, we multiplied the mean 40 -year emission rate with the total abandoned boma areas in semi-arid

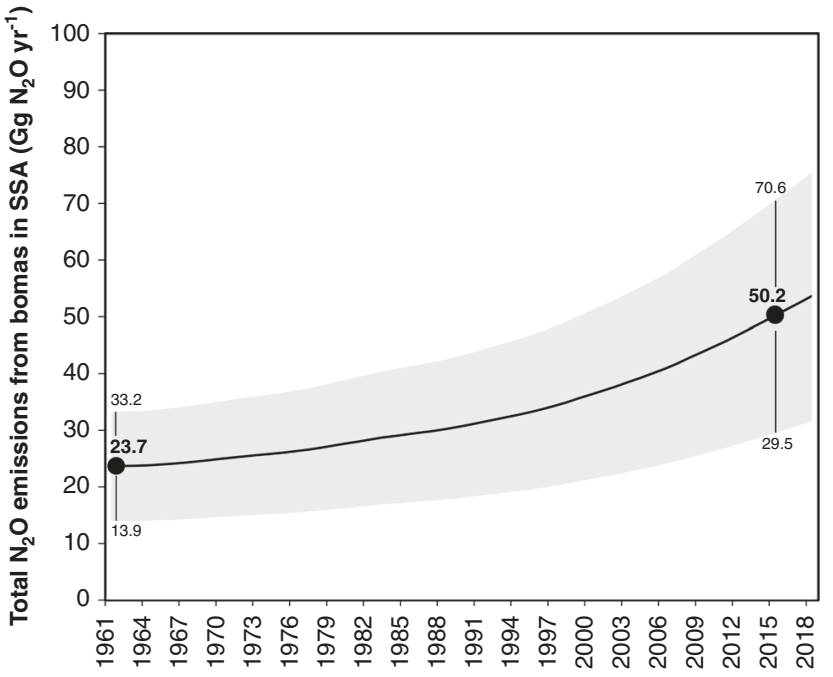

Fig. 3 Change in the source strength of abandoned bomas from 1961 to 2018. The emission trend was based on changes in livestock numbers in semi-arid and arid SSA and the calculation scheme outlined in "Methods". The bold line indicates the median value, while the gray shaded area represents the upper and lower quartiles.

and arid environments in sub-Saharan Africa (SSA), which we estimated for each year. The calculation of annual abandoned total boma area was based on information on animal numbers, area per livestock in bomas, average number of years of boma use, an average number of bomas used simultaneously per herder, and the fraction of bomas that were not extracted for manure (i.e., as fertilizer or for selling) (Supplementary Fig. 7). We developed a range estimate by simulating various scenarios for the combination of the different scaling parameters to explore overall uncertainty of our continental boma $\mathrm{N}_{2} \mathrm{O}$ emissions estimate by Monte Carlo simulation (see Methods, Supplementary Figs. 7 and 8).

According to our calculations, the median of total $\mathrm{N}_{2} \mathrm{O}$ emissions from bomas in semi-arid and arid climates of SSA is $\sim 50.2 \mathrm{Gg} \mathrm{N}_{2} \mathrm{O} \mathrm{yr}^{-1}$ (25-75th percentile: 29.5-70.6 $\mathrm{Gg} \mathrm{N}_{2} \mathrm{O} \mathrm{yr}^{-1}$, Fig. 3) ${ }^{16}$, with the highest $\mathrm{N}_{2} \mathrm{O}$ emissions in countries that have the highest numbers of livestock in pastoral systems, including Ethiopia, North- and South-Sudan, Kenya, Tanzania and Burkina Faso and Nigeria (Fig. 4). This is one magnitude higher than estimates of $\mathrm{N}_{2} \mathrm{O}$ emissions associated with manure management as documented in the EDGAR5 database for the same land area ( $7.7 \mathrm{Gg} \mathrm{N}_{2} \mathrm{O} \mathrm{yr}^{-1}$ ) and comprises $5 \%$ of the current estimate of total anthropogenic $\mathrm{N}_{2} \mathrm{O}$ emissions for Africa at continental scale $\left(\right.$ EDGAR5 $\left.=974 \mathrm{Gg} \mathrm{N}_{2} \mathrm{O} \mathrm{yr}^{-1}\right)$. 

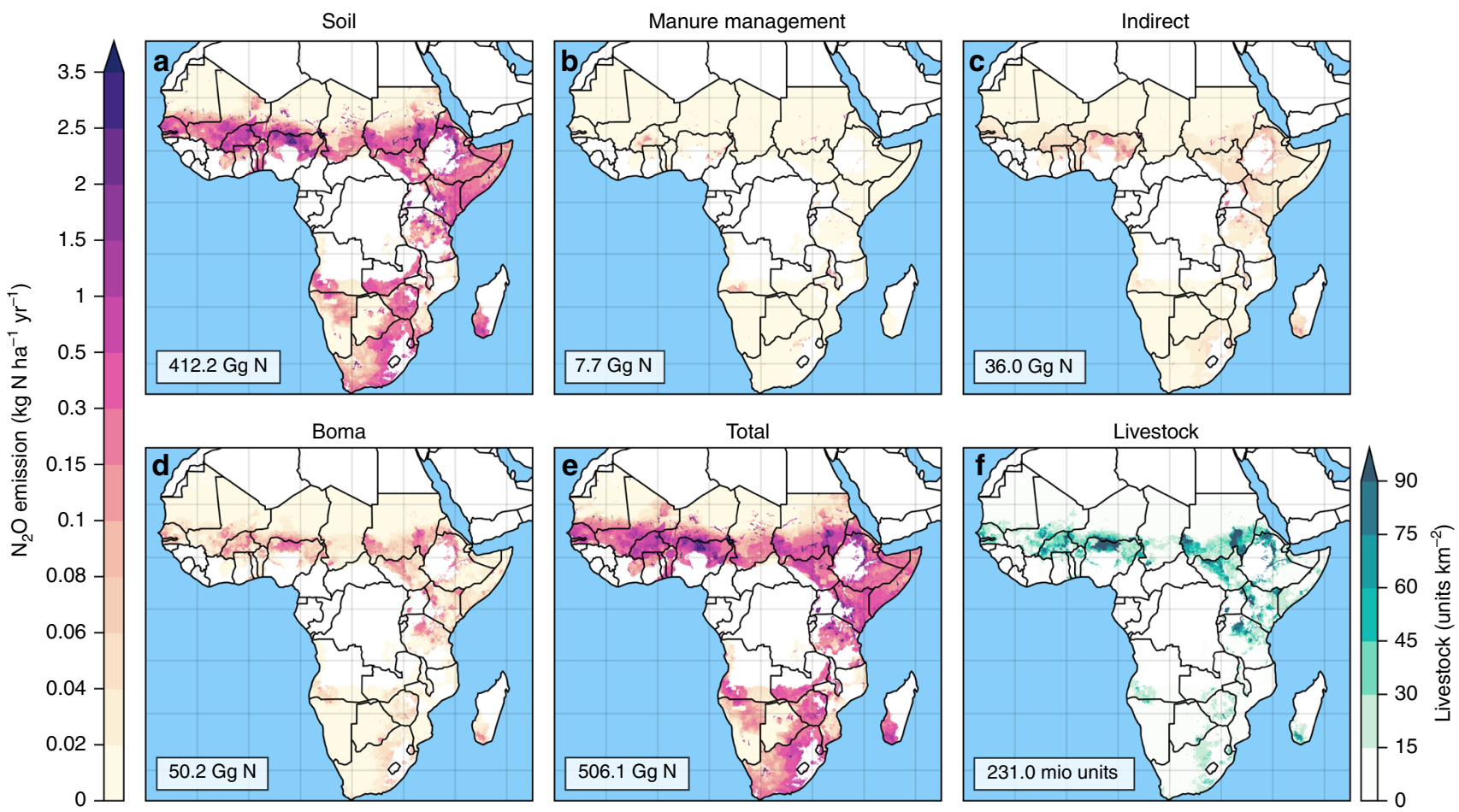

Fig. 4 Sources of agricultural $\mathbf{N}_{\mathbf{2}} \mathbf{O}$ fluxes and livestock units. Given are $\mathrm{N}_{2} \mathrm{O}$ fluxes for semi-arid and arid regions in SSA based on EDGAR5 5 (a: soil; $\mathbf{b}$ : manure management; $\mathbf{c}$ : indirect emissions) and the total $\mathrm{N}_{2} \mathrm{O}$ emissions from bomas $\mathbf{d}$ from this study, and the resulting sum of total agricultural $\mathrm{N}_{2} \mathrm{O}$ emissions $(=a+b+c+d)$ e. $\mathbf{f}$ depicts the livestock density for cattle, sheep, and goats in semi-arid and arid environments in Africa ${ }^{6}$. Livestock units ${ }^{23}$ summarize total number of cattle, sheep, and goats with $N=\left(\sum\right.$ cattle $\left.+\frac{\text { sheep } * 0.1+\text { goats } * 0.1}{0.7}\right)$.

Our measurements of $\mathrm{N}_{2} \mathrm{O}$ emissions from bomas and resulting estimates for semi-arid and arid regions in SSA are relevant in the context of current uncertainties of anthropogenic sources and drivers of $\mathrm{N}_{2} \mathrm{O}$ increases in the atmosphere ${ }^{17}$, showing a systematic underestimation of $\mathrm{N}_{2} \mathrm{O}$ emissions from manure management at the scale of Africa. In 40 years following abandonment, an additional $1.34 \%$ (95\% confidence interval, CI: $0.90-2.56 \%$; Supplementary Note 1 ) of the accumulated manure $\mathrm{N}$ is directly emitted in form of $\mathrm{N}_{2} \mathrm{O}$ that is not considered by current IPCC methodology ${ }^{18,19}$. In addition, Africa's population of livestock has increased exponentially in the last 60 years $^{7}$ (Supplementary Fig. 1), and our results indicate that observed increases in atmospheric $\mathrm{N}_{2} \mathrm{O}$ concentration may not only be linked to the global increase in the use of fertilizers ${ }^{20}$, but also to numbers of livestock in semi-arid and arid regions and the manure accumulation in bomas (Fig. 4).

It was recently suggested that Africa contributed $20 \%$ to the observed increase in global $\mathrm{N}_{2} \mathrm{O}$ emissions between 2000 and 2005 and 2010 and 2015 (or $\sim 0.32 \mathrm{Tg} \mathrm{N} \mathrm{yr}^{-1}$ of the total $1.6 \mathrm{Tg}$ $\mathrm{N} \mathrm{yr}^{-1}$ increase $)^{17}$. Our estimate of the increase in emissions from the abandoned bomas during this period is $0.006 \mathrm{Tg} \mathrm{N} \mathrm{yr}^{-1}$ (or only $2 \%$ of this increase) and therefore cannot explain this difference. However, our measurements from abandoned bomas are biased low, and direct $\mathrm{N}_{2} \mathrm{O}$ emissions from active bomas and indirect $\mathrm{N}_{2} \mathrm{O}$ emissions from leached or volatilized $\mathrm{N}$, which have not been investigated here, may have also contributed to the observed increase in $\mathrm{N}_{2} \mathrm{O}$ emissions from the African continent, and warrants further research.

Given the remoteness of settlements of pastoral communities, there is unlikely to be an economically viable solution for transporting and selling manure. However, simple management practices such as the use of mobile bomas, which can be changed at monthly intervals ${ }^{21}$, annual spreading or the distribution of manure upon abandonment on the adjacent rangeland, would not only significantly decrease $\mathrm{N}_{2} \mathrm{O}$ emissions, but could also work to restore rangeland productivity as nutrients are redistributed in the landscape, thereby creating larger areas with improved, nutrient-rich forage ${ }^{22}$.

\section{Conclusion}

Our results show that $\mathrm{N}_{2} \mathrm{O}$ emissions from bomas have not been adequately considered, and therefore we recommend that current methodology for estimating $\mathrm{N}_{2} \mathrm{O}$ emissions from livestock held by pastoralists in semi-arid and arid landscapes in SSA and elsewhere should be refined to include abandoned bomas. Moreover, further research in understanding indirect emissions due to $\mathrm{N}$ losses from bomas along hydrological (leaching, surface run-off) and atmospheric (mainly $\mathrm{NH}_{3}$ volatilization) pathways is needed to develop a full picture of the importance of abandoned bomas as a source for atmospheric $\mathrm{N}_{2} \mathrm{O}$. To decrease the environmental $\mathrm{N}$ footprint of bomas, improved but simple manure management measures should be considered.

\section{Methods}

Field $\mathbf{N}_{2} \mathbf{O}$ flux measurements. At seven different semi-arid and arid savanna regions in Kenya (Fig. 1, Supplementary Fig. 9), $\mathrm{N}_{2} \mathrm{O}$ measurements from soils at 46 boma sites and 22 adjacent reference sites (undisturbed savanna) were carried out. At each boma and control site, 3-7 plots were chosen randomly for flux measurements. Local members of the pastoral communities, including herders and/ or community elders were interviewed for information on the time since abandonment of each boma.

$\mathrm{N}_{2} \mathrm{O}$ fluxes from bomas were measured using the fast-box chamber method ${ }^{15}$, deploying an ultra-portable greenhouse gas analyzer of ABB-Los Gatos Research Inc. (Modell 909-0041). A gas-tight, vented chamber $(0.3 \times 0.2 \times 0.15 \mathrm{~m})$ was pressed against the ground on foam frames for $4-7 \mathrm{~min}$, during which time sample air was pumped from the headspace of the chamber to the analyzer and returned to the chamber thereafter. In this way, changes in headspace $\mathrm{N}_{2} \mathrm{O}$ concentrations were continuously measured over the sample period, with a running average of every $5 \mathrm{~s}$. Linear regression over the sample period was used to calculate fluxes. The detection limit for $\mathrm{N}_{2} \mathrm{O}$ fluxes was $<1 \mu \mathrm{g} \mathrm{N} \mathrm{N}_{2} \mathrm{O}-\mathrm{N} \mathrm{m}^{-2} \mathrm{~h}^{-1}$. 
Soil and environmental parameters. Environmental variables including gravimetric and volumetric soil water content, soil and air temperatures, organic layer thickness, and aboveground plant biomass (if present) were measured in all plots. At selected boma sites, we also measured total $\mathrm{N}$ and $\mathrm{C}$ stocks for $0-1 \mathrm{~m}$ depth (see Supplementary Table 1 and Supplementary Fig. 9). We noted crusts only on bomas that were abandoned for $<5$ years. As nutrient concentrations diminish with time, vegetation starts to grow on abandoned bomas. Furthermore, owing to rainfall and trampling of wild animals and sometimes of livestock, crusts are fragile, fragmented and $<5 \mathrm{~mm}$ in thickness.

Identifying drivers of $\mathbf{N}_{\mathbf{2}} \mathbf{O}$ fluxes. For regression analyses on controlling parameters of $\mathrm{N}_{2} \mathrm{O}$ fluxes (Supplementary Tables 2-4; Supplementary Notes 2 and 3), we calculated an average flux per boma (or control) site for our analyses. We used Welch's $t$ test to compare $\mathrm{N}_{2} \mathrm{O}$ fluxes from boma and adjacent savanna plots, as well as for comparing $\mathrm{N}_{2} \mathrm{O}$ fluxes from vegetated plots with those from bare soil plots and from plots of high versus low organic layer depth $(>0.3 \mathrm{~m}$ versus $<0.3 \mathrm{~m})$. A depth of $0.3 \mathrm{~m}$ was chosen as a threshold value to distinguish between bomas that were used for 1-2 years and those that were used consecutively for $>2$ years, as manure accumulates at a rate of 0.1 to $0.15 \mathrm{~m} \mathrm{yr}^{-1}$.

To determine the effect of potential driver variables on $\mathrm{N}_{2} \mathrm{O}$ fluxes $(\log 10)$, we explored a multiple regression model for gravimetric soil water content (including a quadratic term to allow a decrease at high soil water content) as well as soil temperature, organic layer $\mathrm{N}$, organic layer $\mathrm{C}$, vegetation cover, time since abandonment, and organic layer depth (Supplementary Table 3 and 4, multiple $r^{2}$ $=0.41$, adjusted $r^{2}=0.26$ ). Only soil temperature significantly affected $\mathrm{N}_{2} \mathrm{O}$ fluxes in the multiple linear regression model. In addition, a mixed modeling approach was used to assess whether random effects (e.g., on site) improved the model. This did not improve the model performance, indicated by a higher AIC (138 versus 91).

To estimate overall $\mathrm{N}_{2} \mathrm{O}$ emissions of bomas over time, we built a simple regression model relating boma age (since abandonment) to average boma $\mathrm{N}_{2} \mathrm{O}$ fluxes on a log-log scale (Supplementary Table 2, displayed in Fig. 2). Since the variability explained by this model is moderate $\left(r^{2}=0.13\right)$, there are relatively wide confidence intervals (Fig. 2), but these reflect the full variability of our measured $\mathrm{N}_{2} \mathrm{O}$ fluxes. From the model fit, we calculated the cumulative $\mathrm{N}_{2} \mathrm{O}$ emission on a per-area basis over 40 years, i.e., including oldest abandoned bomas investigated.

Upscaling $\mathbf{N}_{\mathbf{2}} \mathbf{O}$ fluxes from bomas to SSA. The estimated $\mathrm{N}_{2} \mathrm{O}$ flux over the 40 years period served as an input for upscaling measurements, thereby taking into account uncertainty of estimated $\mathrm{N}_{2} \mathrm{O}$ flux as well as the uncertainty in further parameters used for spatial upscaling (Supplementary Fig. 7 and below).

Gridded estimates of livestock numbers were taken from Gilbert et al. ${ }^{6}$ (Fig. 4f) and restricted to semi-arid and arid environments of SSA (Supplementary Fig. 10). The calculation of total livestock units for pastoral systems (i.e., sum of cattle + goat + sheep) was based on livestock conversion factors as reported by Houerou and Hoste $^{23}$, which are for cattle in herd 0.7 and for sheep and goat 0.1 . Information on the boma area per livestock unit was obtained from Okello et al. ${ }^{24}$. Based on interviews with herders and local experts it became evident that several bomas are used at the same time as herders move their livestock across grazing areas in response to the availability of forage and water and that at least two bomas are simultaneously in use on average-one close to a semi-permanent homestead and one within seasonal grazing areas. The number of years that a boma is used varies considerably across sites, between 1 month to up to several years in this study and confirmed by several others ${ }^{12,25}$, with 3.7 years being the central value. Information on manure extraction from bomas was not available. Based on interviews with herders we assumed for $90 \%$ of bomas manure is either not extracted or irregularly or only partially extracted. Manure use increases in regions with mixed farming, i.e., simultaneous crop and livestock production and short $(<2-5 \mathrm{~km})$ transport distances, and with increasing humidity ${ }^{26}$, but is hardly existing in remote regions with livestock production only, which are in the focus of our study.

Total $\mathrm{N}_{2} \mathrm{O}$ emissions from bomas in semi-arid and arid environments of SSA were calculated as follows:

Step 1: Calculation of total livestock numbers (TLN) by combing population data for cattle, goat and sheep and converting to a single livestock unit, based on conversions for semi-arid and arid environments ${ }^{23}$.

$$
T L N=\sum \text { cattle }+\frac{(\text { sheep } \times 0.1+\text { goat } \times 0.1)}{0.7}
$$

Cattle, sheep, goat: total number of cattle, sheep, goat

Step 2: Calculating boma use intensity (BUI)

$\overline{B U I}=B A L * N B * F M B / Y B$

with

$B A L$ : boma area per livestock, the work of Okello et al. ${ }^{24}$ indicates that the space for one cattle in a boma is $\sim 4-16 \mathrm{~m}^{2}$, central value: 10

$N B$ : number of bomas in use at the same time, interviews and expert knowledge, central value $=2.5$

$F M B$ : Fraction of bomas without use of manure, interviews and expert

knowledge, central value $=0.9$

$Y B$ : years of boma use, interviews and expert knowledge, central value $=3.7$

Note: in 2015 the total area of newly abandoned bomas in semi-arid and arid SSA was estimated at $1792 \mathrm{~km}^{2}$. The total area of semi-arid and arid SSA equals
15.16 Mio $\mathrm{km}^{2}$. Thus, the area of newly abandoned bomas equals $0.11 \%$ of the total area of semi-arid and arid SSA.

Step 3: Calculating $\mathrm{N}_{2} \mathrm{O}$ emission intensity ( $\mathrm{N}_{2} \mathrm{O} \_$int)

$\overline{\mathrm{N}_{2} \mathrm{O} \_ \text {int }}=\mathrm{N}_{2} \mathrm{O} \times \mathrm{N}_{2} \mathrm{O} \_$years $* 4 / 28$

$\mathrm{N}_{2} \mathrm{O}$ : mean average annual $\mathrm{N}_{2} \mathrm{O}$ flux from bomas, this study

$\mathrm{N}_{2} \mathrm{O}$ _years $=$ observed minimum number of years with $\mathrm{N}_{2} \mathrm{O}$ fluxes significantly greater than at adjacent savanna sites $=40$ years

$44 / 28=$ conversion of $\mathrm{N}_{2} \mathrm{O}-\mathrm{N}$ to $\mathrm{N}_{2} \mathrm{O}$

Step 4: Calculating total $\mathrm{N}_{2} \mathrm{O}$ emissions from bomas in semi-arid and arid environments

$$
\begin{aligned}
& \sum \mathrm{N}_{2} \mathrm{O} \text { from bomas }\left(G g \mathrm{~N}_{2} \mathrm{O}\right)=\frac{T L N x \text { BUI } x \mathrm{~N}_{2} \mathrm{O} \_ \text {int }_{10}}{1000000000[=\text { conversiong } g \mathrm{Gg}]} \\
& \text { Or (summarizing steps 1-3) } \\
& \sum \mathrm{N}_{2} \mathrm{O} \text { from bomas }\left(\mathrm{Gg} \mathrm{N} \mathrm{N}_{2} \mathrm{O} \text { over } 40 \text { years }\right)= \\
& \text { TLNx BAL }\left(m^{-2}\right) x N B \times F M B x N_{2} \mathrm{O}\left(\mu g \mathrm{~N}_{2} \mathrm{O}-\mathrm{N} \mathrm{m}^{-2} y r^{-1}\right) x 40\left[=\text { years of } \mathrm{N}_{2} \mathrm{O}\right. \text { flux activity after abandonment } \\
& Y B\left(\text { years }{ }^{*} 1000000000[=\text { conversion to } \mathrm{Gg}] x\left(\frac{28}{44}\right)\left[=\text { conversion } \mathrm{N}_{2} \mathrm{O}-\mathrm{N} \text { to } \mathrm{N}_{2} \mathrm{O}\right]\right.
\end{aligned}
$$

Supplementary Fig. 7 shows histograms, probability distribution functions, and cumulative distribution functions of the different variables used for assessing the uncertainty of the upscaling procedure. To provide statistics such as median, 25 and $75 \%$ percentile values, etc. for upscaled $\mathrm{N}_{2} \mathrm{O}$ emissions we used the Latin hypercube sampling (LHS) method. The concept behind LHS is to divide the cumulative curve of each variable into $n$ equally probable intervals and take a random sample at each probable interval for each variable. The $n$ values obtained for each of the components were then paired with each other to recalculate the equation $\mathrm{n}$ times for assessing the uncertainty in a prediction equation.

\section{Data availability}

The datasets generated during the current study are available in the figshare repository https://doi.org/10.6084/m9.figshare.12793868. Raw data files and graphic files are available from the corresponding author upon reasonable request.

Received: 12 May 2020; Accepted: 18 August 2020; Published online: 15 September 2020

\section{References}

1. WMO. The state of greenhouse gases in the atmosphere based on global observations through 2018. WMO Greenhouse Gas Bulletin 15, 1-7 (2019).

2. IPCC. Climate Change 2014: Synthesis Report. Contribution of Working Groups I, II and III to the Fifth Assessment Report of the Intergovernmental Panel on Climate Change [Core Writing Team, R.K. Pachauri and L.A. Meyer (eds)]. IPCC, Geneva, Switzerland, 151 pp. (2014).

3. Davidson, E. A. The contribution of manure and fertilizer nitrogen to atmospheric nitrous oxide since 1860. Nat. Geosci. 2, 659-662 (2009).

4. Tubiello, F. N. et al. Agriculture, Forestry and Other Land Use Emissions by Sources and Removals by Sinks 1990-2011 Analysis. FAO Statistics Division Working Paper Series ESS/14-02 (2014).

5. Janssens-Maenhout, G. et al. EDGAR v4.3.2 Global Atlas of the three major greenhouse gas emissions for the period 1970-2012. Earth Syst. Sci. Data 11, 959-1002 (2019).

6. Gilbert, M. et al. Global distribution data for cattle, buffaloes, horses, sheep, goats, pigs, chickens and ducks in 2010. Sci. Data 5, 180227 (2018).

7. http://www.fao.org/faostat/en/\#data/QA, visited in March 20, 2020

8. Silva, L. F. P. et al. Nitrogen recycling and feed effificiency of cattle fed protein-restricted diets. Anim. Prod. Sci. 59, 2093-2107 (2019).

9. Gourley, C. J. et al. Nitrogen use efficiency and manure management practices in contrasting dairy production systems. Agric. Ecosys. Environm 147, 73-81 (2012).

10. Muchiru, J. et al. The role of abandoned pastoral settlements in the dynamics of African large herbivore communities. J. Arid Environ. 72, 940-952 (2008).

11. Muchiru, J. et al. The impact of abandoned pastoral settlements on plant and nutrient succession in an African savanna ecosystem. J. Arid Environ. 73, 322-331 (2009).

12. Blackmore, A. C. et al. The origin and extent of nutrient-enriched patches within a nutrient-poor savanna in South Africa. J. Biogeogr. 17, 463-470 (1990).

13. Marshall, F. et al. Ancient herders enriched and restructured African grasslands. Nature 561, 387-390 (2018).

14. Yao, Z. et al. Soil $\mathrm{N}$ intensity as a measure to estimate annual $\mathrm{N}_{2} \mathrm{O}$ and $\mathrm{NO}$ fluxes from natural and managed systems. Curr. Opin. Environm. Sust. 47, 1-6 (2020).

15. Hensen, A. et al. Low cost and state of the art methods to measure nitrous oxide emissions. Environ. Res. Lett. 8, 025022 (2013).

16. Butterbach-Bahl, K. et al. Data on nitrous oxide emissions and flux measurements at various boma sites in Kenya. figshare https://doi.org/ 10.6084/m9.figshare.12793868 (2020). 
17. Wells, K. C. et al. Top-down constraints on global $\mathrm{N}_{2} \mathrm{O}$ emissions at optimal resolution: application of a new dimension reduction technique. Atmos. Chem. Phys. 18, 735-756 (2018).

18. IPCC 2006 IPCC Guidelines for National Greenhouse Gas Inventories, prepared by the National Greenhouse Gas Inventories Programme. Eggleston, H. S., Buendia, L., Miwa, K., Ngara, T., and Tanabe, K. (eds) IGES Japan (2006).

19. IPCC 2019 Refinement to the 2006 IPCC Guidelines for National Greenhouse Gas Inventories. Gómez, D., Irving, W. (eds), IGES Japan (2019).

20. Winiwarter, W. et al. Technical opportunities to reduce global anthropogenic emissions of nitrous oxide. Environ. Res. Lett. 13, 014011 (2018).

21. Poresnky, L. M. et al. Generation of ecosystem hotspots using short-term cattle corrals in an African. Savanna Rangel. Ecol. Manag. 68, 131-141 (2015).

22. Reynolds, A. Q. et al. Ecological sites: can they be managed to promote livestock production? Rangelands 41, 239-243 (2019).

23. Le Houerou, H. N. \& Hoste, C. H. Rangeland production and annual rainfall relations in the Mediterranean basin and in the African Sahelo-Sudanian zone. Rangel. Ecol. Manag. 30, 181-189 (1977).

24. Okello, M. M. et al. Human-carnivore conflicts in private conservancy lands of Elerai and Oltiyiani in Amboseli area, Kenya. Nat. Res 5, 375-391 (2014).

25. Western, D. \& Dunne, T. Environmental aspects of settlement site decisions among pastoral Maasai. Hum. Ecol. 7, 75-98 (1979).

26. Onduru, D. D. et al. Manure and soil fertility management in sub-humid and semi-arid farming systems of Sub-Saharan Africa: experiences from Kenya. Int. J. Agric. Res 3, 166-187 (2008).

\section{Acknowledgements}

We thank George Wanyama, Francis Njenga, and Sheila Okoma for their invaluable support for laboratory analyses. We also acknowledge the staff at Mpala Research Centre for their logistical support. K.B.B. and L.M. received funds via the CGIAR Research Program on Livestock. We thank all donors that globally support our work through their contributions to the CGIAR system. K.B.B., R.K., C.W., and K.F. were partly funded by the Helmholtz ATMO "Atmosphere and Climate" program. J.R. was funded by a grant within the UPSCALERS project (Upscaling Site-Specific Climate-smart Agriculture and Land use practices to Enhance Regional production Systems in West Africa) as funded by the African Union Commission.

\section{Author contributions}

K.B.B., G.G., R.K., and L.M. conceived and designed the study. K.B.B., G.G., L.M., R.K., and M.B. conducted the field work. K.B.B., G.G., J.R., C.W., and K.F. analyzed data, developed the upscaling approach, and established uncertainty analyses. K.B.B. wrote the first draft with all authors contributing to further revisions.

\section{Funding}

Open Access funding provided by Projekt DEAL.

\section{Competing interests}

The authors declare no competing interests.

\section{Additional information}

Supplementary information is available for this paper at https://doi.org/10.1038/s41467 020-18359-y.

Correspondence and requests for materials should be addressed to K.B.-B.

Peer review information Nature Communications thanks Martin Chantigny, Arezoo Taghizadeh-Toosi, and other, anonymous, reviewers for their contributions to the peer review of this work. Peer review reports are available.

Reprints and permission information is available at http://www.nature.com/reprints

Publisher's note Springer Nature remains neutral with regard to jurisdictional claims in published maps and institutional affiliations.

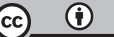

Open Access This article is licensed under a Creative Commons Attribution 4.0 International License, which permits use, sharing, adaptation, distribution and reproduction in any medium or format, as long as you give appropriate credit to the original author(s) and the source, provide a link to the Creative Commons license, and indicate if changes were made. The images or other third party material in this article are included in the article's Creative Commons license, unless indicated otherwise in a credit line to the material. If material is not included in the article's Creative Commons license and your intended use is not permitted by statutory regulation or exceeds the permitted use, you will need to obtain permission directly from the copyright holder. To view a copy of this license, visit http://creativecommons.org/ licenses/by/4.0/.

(c) The Author(s) 2020 